BJHS: Themes 4: 79-98, 2019. C British Society for the History of Science 2019. This is an Open Access article, distributed under the terms of the Creative Commons Attribution-NonCommercialNoDerivatives licence (http://creativecommons.org/licenses/by-nc-nd/4.0/), which permits noncommercial re-use, distribution, and reproduction in any medium, provided the original work is unaltered and is properly cited. The written permission of Cambridge University Press must be obtained for commercial re-use or in order to create a derivative work.

doi:10.1017/bjt.2019.9 First published online 8 August 2019

\title{
The repatriation of the Palaeoamericans: Kennewick Man/the Ancient One and the end of a non-Indian ancient North America
}

\author{
ANN M. KAKALIOURAS*
}

\begin{abstract}
This article considers the repatriation of some the most ancient human skeletal remains from the United States as two sorts of ending: their end as objects of scientific study, and their end as ancient non-American Indian settlers of North America. In the 1990s, some prominent physical anthropologists and archaeologists began replacing 'Palaeoindian' with the new category of 'Palaeoamerican' to characterize the western hemisphere's earliest inhabitants. Kennewick Man/the Ancient One, a nearly nine-thousand-year-old skeleton, convinced some anthropologists that contemporary Native American people (descendants of Palaeoindians) were not biologically related to the very first American colonists. The concept of the Palaeoamerican therefore denied Native American people their long-held status as the original inhabitants of the Americas. New genetic results, however, have contradicted the craniometric interpretations that led to these perceptions, placing the most ancient American skeletons firmly back in the American Indian family tree. This article describes the story of Kennewick Man/the Ancient One, the most famous 'Palaeoamerican'; explores how repatriation has been a common end for many North American collections (Palaeoindians included); and enumerates what kind of ending repatriation may represent materially and ethically for anthropological science.
\end{abstract}

If this individual is truly over 9,000 years old, that only substantiates our belief that he is Native American. From our oral histories, we know that our people have been part of this land since the beginning of time.

Armand Minthorn, Confederated Tribes of the Umatilla Indian Reservation ${ }^{1}$

A windswept plain in South Dakota. The foothills of the Rocky Mountains in Montana. The Columbia river basin in Washington State. These are a few of the places where some of the rarest archaeological finds in the continental United States have been put to rest for a second time. They were known as Palaeoindians - and more recently as

* Department of Anthropology, Whittier College, 13406 E. Philadelphia St, PO Box 634, Whittier, CA, 90608, USA. Email: akakalio@whittier.edu.

I would like to sincerely thank Jenny Bangham, Boris Jardine and Emma Kowal for inviting me to participate in the How Collections End workshop in 2017. I am also very grateful for their incisive suggestions for and critiques of this paper, and for all the work they did to put this issue together. I would also like to thank the other workshop participants for their insightful comments, feedback and ideas.

1 Andrew Slayman, 'Special report: a battle over bones', Archaeology (January-February 1997) 50(1), at https://archive.archaeology.org/9701/etc/specialreport.html, accessed 20 November 2018. 
Palaeoamericans by some archaeologists and biological anthropologists. They are simply called ancestors by Native American peoples. ${ }^{2}$ In American archaeology, the category Palaeoindian has traditionally described the very first people who lived on the continent. The Palaeoindian period began around 13,000 years ago in the continental United States, and ended with the retreat of the ice sheets that covered the northern part of the hemisphere during the last Ice Age. ${ }^{3}$ For most of the twentieth century, archaeologists of North and South America assumed that all skeletal individuals excavated in the western hemisphere, no matter their time period, were related to contemporary Native North Americans or to the indigenous peoples of Central and South America.

The stunning find of a nearly complete ancient skeleton in the western American state of Washington in 1996, however, sparked controversies that swirled around early western hemispheric human remains for the next two decades. Kennewick Man - as he came to be known among anthropologists - or the Ancient One - as he was named by a coalition of Native tribes and nations who claimed him as an ancestor - was nearly nine thousand years old, and morphologically different from today's Native Americans. ${ }^{4}$ Soon after this skeleton was found, biological anthropologists interested in the peopling of the Americas made a point of documenting these physical differences in other Palaeoindian remains that had been found earlier in the twentieth century, and in many cases they found them. ${ }^{5}$ Specifically, divergences in cranial morphology (the size and shape of the skull) between the most ancient individuals unearthed in the Americas and those from more recent indigenous people led some scientists to believe that the hemisphere's earliest inhabitants were not related to Native American people at all. Perhaps they were not American Indian or even the ancestors of today's Indians. ${ }^{6}$ Could they have been some other kind of Asian or Eurasian people who may have left no known descendants?

A few anthropologists - among them Robson Bonnichsen, the founder of the Center for the Study of the First Americans at Texas A \& M University; Douglas Owsley, the head of the Smithsonian Institution's Division of Physical Anthropology; and Richard Jantz, a senior anthropologist at the University of Tennessee - began to call these ancient skeletons 'Palaeoamericans' to conceptually separate them from the Native

2 In the United States, archaeologists are researchers who excavate and interpret the material cultural remains of the past, while biological anthropologists are those who focus on the human skeletal remains that are excavated from archaeological sites.

3 Linda S. Cordell, Kent Lightfoot, Francis McManamon and George Milner (eds.), Archaeology in America: An Encyclopedia, vol. 2, Westport, CT: Greenwood Publishing Group, 2009, p. 33.

4 The Native tribes and nations who claimed the Ancient One as their ancestor included the Confederated Tribes of the Umatilla Indian Reservation, the Confederated Tribes of the Colville, the Yakama Nation, the Nez Percé people and the Wanapum Band.

5 During the summer of 1997 I was present in the osteology laboratory at Hamline University in St Paul, Minnesota when Richard Jantz visited to collect craniometric data from two Palaeoindian skeletons that were housed there.

6 As is convention in American anthropology and archaeology, Native American, American Indian, Indian and Native people and/or Native tribes and nations will be used interchangeably in this article to denote the indigenous people who are cultural or biological descendants of the first peoples who migrated into the western hemisphere. Specific names of Native tribes and nations will be employed when appropriate. 
Americans they assumed followed them in later migrations. As it was portrayed in the literature of the time, "Paleoamerican" has tended to replace the term "Paleoindian" among skeletal biologists ... since Paleoindian infers some kind of American Indian. Clearly, some of the most ancient Americans are not "American Indian" in traditional racial terms."7 Therefore ancient skeletons from the earliest time period of human occupation in the Americas who had cranial features different from modern Native people - all of which were originally called Palaeoindian - were redesignated by these notable scientists as Palaeoamerican. While Palaeoamerican as a category was not taken up by American anthropology as a whole, its usage among these wellknown scientists perpetuated the idea that there was an ontological distinction between the first Americans and Native American peoples. This idea also exploded into the popular press, generating numerous newspaper and magazine articles in the late 1990s, including a feature in the New Yorker, a public television documentary, and a spot on 60 Minutes, a long-running investigative news programme - all of which featured the aforementioned Douglas Owsley as an expert interviewee, claiming that Kennewick Man/the Ancient One was different from Native Americans. ${ }^{8}$ The Palaeoamerican category briefly captured the American popular imagination, in particular for the insinuation that if the first Americans were not American Indians, they were perhaps 'Caucasoid'. James Chatters, the forensic archaeologist who was called to excavate Kennewick Man/ the Ancient One from the banks of the Columbia river, used that antiquated racial term to describe the non-Indian features of the skull; much of the press have uncritically glossed 'Caucasoid' as 'European' ever since. ${ }^{9}$ More insidiously, claims that Kennewick Man was not Native American led some white nationalist groups to claim that he was an ancient European (white) man, and that white people were the actual first inhabitants of the Americas. ${ }^{10}$

Since the mid-1990s, then, Palaeoamericans have vied with Palaeoindians for the status of the very first people of the Americas. Native tribes and nations from the various regions where these ancient remains were excavated, though, have consistently called for their repatriation. As Armand Minthorn, a trustee of the Confederated Tribes of the Umatilla, has said, 'Ever since the Kennewick Man was discovered ... we have always claimed he is Native American, from the very first day.' ${ }^{11}$ In 1996, the US

7 George W. Gill and Carlos J. Jimenez, 'Paleoamerican skeletal features surviving into the Late Plains Archaic', in Bradley T. Lepper and Robson Bonnichsen (eds.), New Perspectives on the First Americans, College Station: Texas A \& M University Press, 2004, pp. 137-141, 138.

8 'Kennewick Man', 60 Minutes, 28 October 1998, at www.cbsnews.com/videos/kennewick-man, accessed 1 June 2017; Douglas Preston, 'The lost man', New Yorker, 16 June 1997, pp. 70-81; 'Mystery of the first Americans', PBS NOVA, at www.pbs.org/wgbh/nova/first/claimowsl.html, accessed 22 November 2018.

9 Timothy Egan, 'Old skull gets white looks, stirring dispute', New York Times, 2 April 1998, p. A12; Rebecca Morelle, 'DNA reignites Kennewick Man debate', BBC News, at www.bbc.com/news/scienceenvironment-33170655, accessed 27 November 2018.

10 For a comprehensive picture of the many attitudes that circled around Kennewick Man/the Ancient One, see Heather Burke, Claire E. Smith, Dorothy Lippert, Joe Watkins and Larry Zimmerman (eds.), Kennewick Man: Perspectives on the Ancient One, Walnut Creek, CA: Left Coast Press, 2008.

11 Armand Minthorn, 'Bringing the Ancient One home', DNA and Indigeneity: The Changing Role of Genetics in Indigenous Rights, Tribal Belonging, and Repatriation, an IPinCH project public symposium, 2015, at www.youtube.com/watch?v=En9ADTX5eiY, accessed 23 October 2018. 
federal government, who owned the land on which Kennewick Man/the Ancient One was found, took steps to repatriate him to the Confederated Tribes of the Umatilla Nation and their neighbouring tribes and nations. However, seven anthropologists, including Bonnichsen, Owsley, Jantz and other well-known professionals in both biological anthropology and archaeology, filed a lawsuit to prevent the federal government from repatriating Kennewick Man/the Ancient One to the five northwestern tribes who claimed him. ${ }^{12}$ For the plaintiff scientists, who wanted to preserve Kennewick Man/the Ancient One for study, deeming a skeleton Palaeoamerican severed the cultural and biological ties between the ancient remains and living Native peoples. With these connections in doubt, the United States' federal law that governs the repatriation of ancestral remains to Native peoples - NAGPRA (Public Law 101-601, or the Native American Graves Protection and Repatriation Act) - no longer applied. NAGPRA states that human remains either must be directly culturally affiliated with a living federally recognized Native American tribe or nation, or be affiliated with a non-federally recognized tribe or nation who can marshal the support of a federally recognized group to sponsor their repatriation claim. There are thousands of unaffiliated Native remains (CUHR culturally unaffiliated human remains) that are still curated by both museums and academic institutions in the United States. The issue with the Palaeoindians/ Palaeoamericans was, more specifically, that their 'Native Americanness' was being questioned. If these individuals were not only not culturally affiliated with an extant group, but actually not Native American at all, tribes and nations would never be able to claim them for repatriation or reburial. The anthropologists who sued to retain the remains of Kennewick Man/the Ancient One won the case, principally because the federal judge agreed with their craniometric data; the skull was not similar to Native American people morphologically, so therefore was not Native American. ${ }^{13}$ NAGPRA would not apply to the Kennewick Man/the Ancient One skeleton, and he would remain at the Burke Museum in Seattle for over two decades.

In the last few years, though, genetic technology has fundamentally changed this previously intractable situation. Recent technical advances in DNA extraction from ancient remains have allowed viable uncontaminated DNA sequences to be analysed from some of these skeletal individuals. In each case where genetic material has been successfully sequenced and studied, the closest genetic relatives were determined not only to be modern Native Americans, but also to be the local and regional Native people who had claimed the remains as their ancestor in the first place. ${ }^{14}$ Hence Palaeoamericans, including Kennewick Man/the Ancient One, have begun to disappear from museums and universities as these institutions are now honouring Native repatriation requests.

Behind the emergence of these impressive DNA sequencing results (and their subsequent wide-ranging practical implications) is a long-running contest between two scientific methods of ancient skeletal analysis: craniometry and genetics. It is important to

12 Bonnichsen et al. v. The United States, United States Court of Appeals, Ninth District, at https://caselaw. findlaw.com/us-9th-circuit/1420091.html, accessed 20 November 2018.

13 Bradley T. Lepper, 'Judge rules scientists can study Kennewick Man', Friends of America's Past, at www. friendsofpast.org/kennewick-man/news/021128-lepper.html, accessed 20 November 2018.

14 David J. Meltzer, 'Kennewick Man: coming to closure', Antiquity (2015) 89(348), pp. 1485-1493. 
note that each of these methods is only relevant to repatriation where there are no grave goods or sacred objects in the vicinity of the remains that can establish a cultural affiliation with Native people. Until the last decade or so, in those instances, craniometry dominated efforts to culturally classify skeletal individuals and collections, principally because problems of sample acquisition and contamination in ancient DNA research made these analyses difficult, if not impossible. For example, in the year 2000, scientists were unable to obtain usable DNA from Kennewick Man/the Ancient One, thereby leaving his identity, for a time, in the hands of craniometry. ${ }^{15}$

This article is about the end of the Palaeoamericans as a designation for a class of precious objects. First, it is about Palaeoamericans ending as a loosely organized collection, since they are increasingly being given back to Native American peoples. To explain this ending, I consider the history of repatriation in the United States, and the ethical and cultural shifts that have made the repatriation of ancient skeletal remains to Native tribes and nations possible. Second, the end of the Palaeoamerican as a valid scientific concept has been all but sealed because of the demonstrated genetic links between some skeletons classified as Palaeoamerican and modern Native peoples. For the most part, there are now only Palaeoindians, a reversion to a pre-1990s moment in the biological anthropology of the Americas. ${ }^{16}$ Here I focus on how the aforementioned genetic results have ended craniometry's authority to classify ancient American skeletons. I illustrate this second kind of ending by further fleshing out the story of Kennewick Man/the Ancient One, the skeleton at the focus of the conflict between Palaeoindian and Palaeoamerican, and between the two methods of craniometry and genetics. $^{17}$

The first facet of the Palaeoamerican story, then, is the material end to skeletal collections that repatriation and reburial represent. In the United States, the repatriation of human remains, associated burial artefacts and sacred objects to Native American tribes and nations has been a legislative and practical reality since the 1980s. A number of states first passed laws that both protected Native gravesites and allowed for repatriation, and in 1990 these statutes were superseded by the aforementioned federal law. Repatriation has largely ended how science was traditionally practised on Native American materials. This ending, though, has been a long time coming. Before the Native American reburial movement was initiated with the Indian activism and cultural revitalization of the 1960 s and 1970 s, repatriation was nearly non-existent. ${ }^{18}$ Furthermore, before NAGPRA, repatriations happened on a case-by-case basis in a

15 See Noreen Tuross and Connie J. Kolman, 'Potential for DNA testing of the human remains from Columbia Park, Kennewick, Washington', at www.nps.gov/archeology/kennewick/tuross_kolman.htm, accessed 12 April 2018.

16 To date not every ancient skeleton has been subjected to DNA analysis.

17 I will be using the somewhat awkward 'Kennewick Man/the Ancient One' to refer to this ancient skeleton, in recognition of the different naming practices of the biological anthropologists and Native people who claimed the remains as their own.

18 See Clayton W. Dumont, Jr, 'Contesting scientists' narrations of NAGPRA's legislative history: rule 10.11 and the recovery of "culturally unidentifiable" ancestors', Wicazo Sa Review (2011) 26(1), pp. 5-41; Kathy Fine-Dare, Grave Injustice: The American Indian Repatriation Movement and NAGPRA, Lincoln: University of Nebraska Press, 2002. 
political and legal environment where scientists exerted much of the control over the process. Even after NAGPRA, Native remains and artefacts have not simply been turned over indiscriminately. Each claim and each repatriation event is usually the product of a series of negotiations, consultations, and accommodations months or even years in the making. Therefore I consider the characteristics of repatriation as an ending, and I discuss the kinds of roles and responsibilities both Native people and scientists can play and have played in the process of returning human remains to the earth. The breaking up of this rare collection of ancient remains - an assemblage that never actually existed under the same roof - portends the decline of the relevance of the term 'Palaeoamerican' to archaeological and skeletal studies. ${ }^{19}$ Some of these skeletal individuals, as mentioned above, have now been reburied according to local tribal traditions, put back into the ground near their original grave locations. Others have been repatriated to Native American tribes and nations, who will either rebury them or curate them on their own terms. Still others remain in museums and at universities, their status uncertain. Whatever their status, they once again enjoy the distinction of being the most ancient American Indians to have lived and died on American soil.

Second, the ways in which a few prominent scientists constructed Kennewick Man/the Ancient One as Palaeoamerican stoked both the scientific and the political fray over the human beginnings of ancient America. After Kennewick Man/the Ancient One was found eroding out of the Columbia river (near the town of Kennewick, WA), the anthropologists who were plaintiffs in the lawsuit to prevent his repatriation constructed Palaeoamericans as a collection, distinct from both the temporal and historical contexts from which they came. That is, there were a number of ancient skeletons between about ten thousand and eight thousand years old already held in US museums and universities. All of these skeletons, numbering fewer than fifteen in total, were excavated from the middle and western United States, a massive geography that would usually disqualify them from being considered members of the same biological population. Nevertheless, they became linked and thought of as a single collection through their supposed status as non-Native American. ${ }^{20}$ The genetic reclassification of some of the most notable Palaeoamericans as Native American has brought this category, and collection, to a rather unanticipated end. For the last thirty years, biological anthropologists have expected collections to end through repatriation - that is, through a successful claim from a Native American tribe or nation. They did not expect that these ancient skeletons, though, would come to such an end. The genetic results, however, have led to the quiet

19 The terms 'Palaeoamerican' and 'Palaeoindian' are still in use in recent publications in archaeology and physical anthropology by United States scholars. The term 'Palaeoindian', in the last year, has dominated article titles by a ratio of nearly four to one. In the five years before 2017, the ratio was three to one (as searched through Yale University's 'Articles+' system at http://yale.summon.serialssolutions.com). 'Palaeoamerican' was largely used to refer directly to the humans who inhabited the Americas first, just like 'Palaeoindian' was before the 1990s. 'Palaeoamerican', then, can continue to be used correctly as a geographical term in reference to the Americas. However, the term's origin is tied directly to human skeletal material, and if more and more skeletons are found to be directly ancestral to Native American people, I believe the term 'Palaeoindian' will predominate even more in the associated literature.

20 Richard L. Jantz and Douglas W. Owsley, 'Variation in early North American crania', American Journal of Physical Anthropology (2001) 114, pp. 146-155. 
repatriation of a number of these ancient skeletons. After considering repatriation, I will turn to the unique end of the Palaeoamericans as a category - in this crucible of craniometric versus genetic results - to magnify how they reflect more general trends in the changing landscape of archaeology and anthropology in the United States.

\section{Repatriation and reburial: material and ephemeral ends}

The ending of collections through repatriation or reburial - what I will describe below as a development for both Native peoples and anthropologists - can be a difficult process for all of the parties involved. In the 1980s and 1990s, scientists and museum curators realized that Native American people had not just cultural, moral or historical but legal standing to reclaim their material ancestral past. Across the United States, many repatriations and reburials have happened since, and in 2010 new regulations that allow for the repatriation of culturally unidentifiable remains were appended to NAGPRA, signalling more repatriations to come. ${ }^{21}$ For academics and museum workers, repatriation has challenged the mandate - codified or uncodified - that researchers should always work to preserve the surviving materials of the past for perpetual study. ${ }^{22}$ For Native peoples, too, repatriation and reburial have been a trying process. Repatriation evokes the conditions under which their ancestors were acquired by museums and academic institutions in the first place - the colonial control that inequitably constructed Native cemeteries as archaeological sites, when European and Euroamerican graves were typically, and respectfully, preserved in situ. ${ }^{23}$ Further, NAGPRA also requires consultation between institutions and Native tribes and nations, but compliance with those requirements has been inconsistent, and sometimes non-existent. ${ }^{24}$ Some Native groups also lack the material or bureaucratic resources to pursue repatriation claims when they are notified by an institution that it holds their ancestral remains or objects. ${ }^{25}$ While

21 US Federal Law: NAGPRA, PL-101-601, 43 CFR 10.11, 'Disposition of culturally unidentifiable human remains'.

22 For example, the Society for American Archaeology's Principles of Archaeological Ethics', at www.saa. org/AbouttheSociety/PrinciplesofArchaeologicalEthics/tabid/203/Default.aspx, accessed 13 February 2018. This states very plainly in the first principle, 'It is the responsibility of all archaeologists to work for the long-term conservation and protection of the archaeological record.'

23 Two pieces of American federal legislation, the Antiquities Act (1906) and the Archaeological Resources Protection Act (1979), helped specifically define Native American sites and the materials that come from them as archaeological resources. Similarly, many unmarked African American cemeteries were looted and excavated by laypeople throughout the southeastern and northeastern United States, with only a notable few receiving professional archaeological excavation. For an example see the 'African Burial Ground National Monument', at www.nps.gov/afbg/index.htm, accessed 15 February 2018.

24 For example, at the University of California, Berkeley, a new NAGPRA committee was recently formed to speed the process of repatriation at that institution. Berkeley is notorious in the repatriation community for refusing to return remains (personal communication, Amy Lonetree). See also Richard C. Paddock, 'Native Americans say Berkeley is no place for their ancestors', Los Angeles Times, 13 January 2008, at www. latimes.com/archives/la-xpm-2008-jan-13-me-bones13-story.html.

25 The initial mandate of NAGPRA was for all museums and academic institutions that held Native American remains and associated funerary objects to compile inventories of all those items, send letters to the tribes and nations involved, and publish those inventories in a standard format in the Federal Register, a notice publication of the US government. Many Native peoples were aware of specific remains and artefacts 
fundamental pro- and anti-repatriation perspectives continue to be articulated in the United States, my aim here is not to review those positions. ${ }^{26}$ Instead, I will describe repatriation as an ending as well as a set of beginnings for the American sciences that attend to the distant past.

First, repatriation has not been the dramatic end that scientists anticipated. In the heat of the reburial movement and the subsequent passage of NAGPRA, researchers forecast the extinguishing of entire academic disciplines, fields of study, or museums in the United States. ${ }^{27}$ That initial fear has not materialized. Collections have certainly been lost, affecting individuals who were attached to specific collections because of their academic commitments. ${ }^{28}$ Nevertheless, archaeology, biological anthropology and museum studies have continued apace, advancing theoretically, technologically and ethically in the last few decades. ${ }^{29}$ Repatriation has also not been a monolithic kind of end that produces the same results or changes for every institution, researcher, tribe or nation. ${ }^{30}$ For example, the Chumash of central California, because of their historically collaborative relationships with biological anthropologists, consented to have remains repatriated to

in certain museums, but the extent of these collections was literally unknown before NAGPRA's passage. Therefore some tribes were inundated with these inventory notices from institutions all around the country.

26 For recent pro-repatriation views see Sangita Chari and Jaime M.N. Lavallee (eds.), Accomplishing NAGPRA: Perspectives on the Intent, Impact, and Future of the Native American Graves and Repatriation Act, Corvallis: Oregon State University Press, 2013; for recent anti-repatriation literature see Elizabeth Weiss, Reburying the Past: The Effects of Repatriation and Reburial on Scientific Inquiry, New York: Nova Science Publishers, 2008.

27 This situation holds for Canada as well, where archaeology and physical anthropology continue, but in an environment where First Nations people have much more influence over how and when remains are excavated and studied. Canada, too, does not have a national law that governs repatriation, so potential repatriations happen on a case-by-case basis (Chelsea Meloche, personal communication). In Australia, however, indigenous human remains were swiftly removed from museums and reburied (Emma Kowal, personal communication).

28 Ann M. Kakaliouras, 'When remains are "lost": thoughts on collections, repatriation, and research in American physical anthropology', Curator: The Museum Journal (2014) 57(2), pp. 213-223.

29 Anecdotally, I have never witnessed a student or professional leave anthropology, or their established position, because of repatriation. Some of my colleagues have switched their specializations from the United States to other countries where repatriation is not practised, but the field of North American archaeology remains incredibly active. In the United States the more pressing threat to educating a next generation in the social sciences and humanities is the increasing emphasis on and funding for STEM (science, technology, engineering and mathematics) fields in higher education. A recent article in the UK's Guardian newspaper also substantiates this situation for British archaeology: 'British archaeology is in a fight for survival', at www.theguardian.com/science/2017/jun/20/trouble-brewing-british-archaeology, accessed 15 February 2018. Furthermore, increasing use of adjunct labour in the college classroom and the concomitant shrinkage of permanent professor positions has utterly transformed the maintenance and growth of academic programmes. Museums have also been adapting to a newer world, but one that's been brought about by the Internet and changes in how Americans spend their leisure time.

30 NAGPRA does not prevent institutions from initiating repatriations of remains not covered by the law. For example, remains that do not share a cultural or biological connection to a specific living Native tribe or nation do not typically need to be listed as available for repatriation. Yet many institutions who house these remains have voluntarily entered into negotiations with Native people over their collections, their past relationships and their potentially collaborative futures. Other institutions have not. These relationships, then, differ from region to region just as institutions and Native groups differ from place to place in the United States. 
them kept in an underground vault on their land, where qualified researchers may have access to them. In other regions of the country, relationships remain tense. In southern California, a few anthropologists sued to stop the repatriation of two ancient skeletons to the Kumeyaay people. In this case, the University of California, which owns the land on which the remains were found, wanted to repatriate the remains. However, the anthropologists - also university employees - wanted to be able to study and collect DNA from the remains. The case went all the way to the United States Supreme Court, which declined to hear it. ${ }^{31}$ Eventually the ancient skeletons were repatriated with no DNA analysis, though the Kumeyaay have not ruled out that possibility. Similarly, in 1999 two ancient skeletons in Minnesota - Browns Valley Man and Minnesota Woman - were reburied in South Dakota along with over a thousand other culturally unidentifiable individuals. Biological anthropologists and Native people in Minnesota had been working together since the late 1980s, with state funding, to repatriate and rebury nearly all the human remains in the state. ${ }^{32}$ The Minnesota Indian Affairs Council, though, allowed the anthropologists to study the remains before they were reburied. Although the skeletons are no longer available, the records and data produced from thousands of sets of human remains still exist and are available for potential future examination with the permission of the tribes. ${ }^{33}$

All these (and more) are the varied kinds of material ends that skeletal collections have experienced since repatriation became a recognized process, transforming the relationships between museums, academic institutions and Native American tribes and nations. There are, though, other more ephemeral ends that have transpired because of repatriation. As mentioned above, with repatriation the expectation of perpetual curation and unfettered availability for study has come to an end. This scholarly expectation was born in the United States during the collection and preservation frenzy of the late nineteenth and early twentieth centuries, the age of 'salvage anthropology' when Native American people were supposedly in the process of disappearing forever. ${ }^{34}$ When Native people did not disappear, and came back to museums and universities in the 1960s and 1970s looking to reclaim their ancestors, their interests in regaining control of their material heritage rarely converged with the scientific purposes to which their ancestors' remains had been put. Then and now, there is a distinct difference between the affective relationships that Native people have with skeletal remains and sacred objects, and the sincere, but culturally removed, fascination of most scientists toward the same items. That is, the spiritual and emotional connections that many Native people express in the presence of their ancestors and ancestral objects has

31 Carl Zimmer, 'Tribes’ win in fight for La Jolla bones clouds hopes for DNA studies', New York Times, 29 January 2016, www.nytimes.com/2016/02/02/science/tribes-win-in-fight-for-la-jolla-bones-clouds-hopes-fordna-studies.html, accessed 15 February 2018.

32 In the interest of full disclosure, I went to college in Minnesota and as a student in biological anthropology I participated in the Minnesota Human Remains Project, from 1992 to 1995.

33 The scientific study of records associated with skeletal remains, instead of the remains themselves, is still relatively rare. In the last few years I have seen a few poster presentations at the Western Bioarchaeology Group (https://sites.google.com/site/westernbioarchaeologygroup/home) conference that have analysed previously collected data.

34 Fine-Dare, op. cit. (18). 
troubled the common Euroamerican notion that the scientific study of the Native American past benefits all people, including Native peoples themselves. In the late 1990s, when repatriation debates were still a hot topic in the archaeological literature, Native scholars pointedly said that their people had received neither health, material nor any other benefit from the study of their ancestors' remains; to them it seemed that the only benefits had been for the careers of Euroamerican scientists. ${ }^{35}$ The end I am identifying here, therefore, is so far a potential one - the end of anthropologists' ability to study Native remains without Native involvement. Such an end has been hastened in Indian Country, as more and more tribes and nations have composed their own institutional review boards (IRBs) that have the authority to approve or deny research requests involving materials and land under their control. ${ }^{36}$

For Native peoples, repatriation also marks the end of the separation between themselves, their ancestors, and many of their sacred objects. This reunification has both been inspired by, and led to, cultural revitalization among many Native groups. ${ }^{37}$ Repatriation and reburial ceremonies have strengthened community bonds through ritual, and through ongoing care of their own historical artefacts and sacred objects. Repatriation, therefore, signals the end of science's monopoly on how those remains should be treated. To care for skeletal remains scientifically means to keep them in temperature- and humidity-controlled storage for as long as possible. However, Native peoples now have the right to care for the remains of their ancestors in ways consistent with their own cultural practices. As Gary Burke, chairman of the Confederated Tribes of the Umatilla Board of Trustees, noted after Kennewick Man/the Ancient One was repatriated, 'The Confederated Tribes of the Umatilla Indian Reservation is proud to have worked with all parties to repatriate the Ancient One to the Tribes. We jointly believe in respecting our ancestors of our past and have fulfilled our responsibility to finally lay the Ancient One to rest.'38

35 Devon A. Mihesuah, 'Introduction', in Mihesuah (ed.), Repatriation Reader: Who Owns American Indian Remains?, Lincoln: University of Nebraska Press, 2000, pp. 1-15; Dumont, op. cit. (18).

36 See, for example, Sara Chandros Hull and David R. Wilson (Diné), 'Beyond Belmont: ensuring respect for AI/AN communities through tribal IRBs, laws, and policies', American Journal of Bioethics (2017) 17(7), pp. 60-62. The development of tribal control over anthropological research has also exposed a tension between how scientists are trained in the United States and the conditions under which they may actually practise. There are many institutions and scholars with hard-won productive and collaborative relationships with Native American tribes and nations. These people are certainly passing this ethic on to their undergraduate and graduate students. However, the bulk of the educational materials available (such as monographs, advanced textbooks and research articles in the fields of archaeology and physical anthropology) are still mostly technical, and also subject to peer-review processes that demand that novel knowledge be the main product of the research. There are relatively few, then, publications which showcase the ethical processes involved in research. Further, I am aware of no publications at all that serve as comprehensive practical guides for graduate students or early-career professionals to the ethical landscape that repatriation has created in the United States.

37 See, for example, Gerald T. Conaty (ed.), Repatriation and the Restoration of Blackfoot Cultural Confidence, Edmonton, Alberta: Athabasca University Press, 2015; and Ann M. Tweedy, Drawing Back Culture: The Makah Struggle for Repatriation, Seattle: University of Washington Press, 2002.

38 Chuck Sams, 'The Ancient One finally laid to rest', at http://ctuir.org/communications/ancient-onefinally-laid-rest, accessed 20 November 2018. 
In other cases, the legal struggles between scientists and Native people over Palaeoindian/Palaeoamerican remains exemplify repatriation as a contentious ending. The tribes and nations that claimed Kennewick Man/the Ancient One did not want the remains studied at all. Nevertheless, the process of the suit itself subjected the remains to a battery of scientific analyses, as the federal Interior Department appointed independent scientists to establish the cultural affiliation of the remains. Also, the public controversy over Kennewick Man/the Ancient One, erupting soon after the remains were found, involved anthropologists, such as the plaintiffs in the case, who had no previous relationship with tribes and nations in the area, and quickly proceeded to the question whether the remains were Indian at all. The fame of these ancient skeletons, then, attracted the attention of new potential stakeholders to their fate. These combined to produce a particularly public and acrimonious fight over this ancient person, in which polarized views on scientific study became rapidly calcified.

In more mundane cases, where neither the skeletal remains nor any living people involved attract national or international media attention, descendant communities and researchers often reach a harmonious mutual agreement about what kind of study will be permitted. These relationships have often taken years to develop, and have involved compromises on all sides. Thus, far from being a unilateral end for skeletal biological or archaeological study, repatriation represents an end for the wholesale ability of scientists to study remains without consultation with or consent from the affected Native tribes or nations.

I will now turn to the details of how the controversy around the first skeleton to have been named a Palaeoamerican, Kennewick Man/the Ancient One, rekindled the drive in some biological anthropologists to resist repatriation. The scientists who fought in the courts to retain the Kennewick Man/Ancient One skeleton defined a scientific category that would make a collection of the most ancient remains in North America immune from NAGPRA, at least for a time. In the end, their efforts failed, and the fight to retain Palaeoindian remains not only damaged the fragile public relationships between Native peoples and anthropology, but also pitted craniometry against a relative newcomer to repatriation struggles: genetics.

\section{Craniometry, genetics and the original Palaeoamerican}

Let us begin this tale at the end. On 18 February 2017 the skeletal individual known as Kennewick Man, or the Ancient One, was reburied at an undisclosed location in Washington State's Columbia basin. ${ }^{39}$ Representatives of five northwestern tribes visited the Burke Museum in Seattle where they received the remains, and the very next day they committed the bones back to the earth. ${ }^{40}$ The tribes had waited a little over two decades for this result, enduring objections from prominent physical

39 Alene Tchekmedyian, 'After two decades, the Kennewick Man is reburied', Los Angeles Times, 20 February 2017, at www.latimes.com/nation/la-na-kennewick-man-reburial-20170220-story.html, accessed 20 March 2017.

40 See note 4 above for the Native tribes and nations who claim the Ancient One as their ancestor. 
anthropologists, losing two legal battles, and witnessing spates of mainstream media coverage that generally represented their perspectives as anti-science, irrational and quaint. ${ }^{41}$ Meanwhile, with this reburial scientists permanently lost access to one of the oldest, most complete skeletons excavated in the western hemisphere, from which, according to their perspective, there was much more to learn. ${ }^{42}$

Although the battle over Kennewick Man/the Ancient One was dramatic, from the point of view of many Native peoples it is merely one struggle among many over the fate of excavated skeletal remains in the United States. Although NAGPRA has not completely solved the conflicts between anthropologists and Native people, over the last few decades the law, as illustrated above, has sensitized the archaeological and biological anthropological communities to the sovereign right of Native tribes and nations to claim their dead, as well as to the idea that indigenous people should be involved in the excavation, and even in the interpretations, of their skeletal ancestors. ${ }^{43}$

In another sense, though, the conflict over Kennewick Man/the Ancient One was very different from other clashes over the repatriation or reburial of most other indigenous human skeletal remains. The anthropologists who objected to the tribes' repatriation request cited the age of the remains and, crucially, the way the skull looked, to argue that Kennewick Man/the Ancient One was not Native American at all - but Palaeoamerican - and therefore not subject to NAGPRA's repatriation provisions. ${ }^{44}$ As explained in the introduction, craniofacial morphology, measurements that define the size and shape of the features of the skull and face, placed Kennewick Man/the Ancient One outside the normal range of variation of other both pre-colonial and modern Native American skulls and faces. The scientists used these metrical differences to contend that this ancient individual was perhaps related to the Ainu of Japan, or to other indigenous peoples of Asia. ${ }^{45}$ Kennewick Man/the Ancient One, therefore,

41 For example, see 'Kennewick Man', op. cit. (8); Preston, op. cit. (8).

42 Brenda J. Baker, Tamara L. Varney, Richard G. Wilkinson, Lisa M. Anderson and Maria A. Liston, 'Repatriation and the study of human remains', in Tamara Bray (ed.), The Future of the Past: Archaeologists, Native Americans, and Repatriation, New York: Garland Publishing, 2001, pp. 69-89.

43 For a comprehensive treatment of one museum's journey through NAGPRA and repatriation see Chip Colwell, Plundered Skulls and Stolen Spirits: Inside the Fight to Reclaim Native America's Culture, Chicago: The University of Chicago Press, 2017; see also Sonia Atalay, 'Indigenous archaeology as decolonizing practice', American Indian Quarterly (2006) 30(3-4), pp. 280-310; Dorothy Lippert, 'The rise of Indigenous archaeology: how repatriation has transformed archaeological ethics and practice', in Thomas Killion (ed.), Opening Archaeology: Repatriation's Impact on Contemporary Research and Practice, Santa Fe: The School for Advanced Research Press, 2008, pp. 151-160.

44 Douglas W. Owsley and Richard L. Jantz, 'Archaeological politics and public interest in Paleoamerican studies: lessons from Gordon Creek Woman and Kennewick Man’, American Antiquity (2001) 66(4), pp. 565575 .

45 On the cranial position of Kennewick Man see Douglas W. Owsley and Richard L. Jantz, 'Kennewick Man: a kin? Too distant', in Elazar Barkan and Ronald Bush (eds.), Claiming the Stones/Naming the Bones: Cultural Property and the Negotiation of National and Ethnic Identity, Los Angeles: Getty Research Press, 2002, pp. 141-161. Additionally, not all physical anthropologists agreed with the use of craniometrics to evaluate the skeleton's cultural position. There are a few factions within the field who fall on different sides of the utility of craniometrics, and those who do not subscribe to the idea that cranial measurements can fix a skeleton's identity made their case known in the academic literature. The main charges about craniometry from within physical anthropology that were published came from this piece: George J. Armelagos and 
potentially represented a different migration of people into the western hemisphere, people who were not the ancestors of today's Native Americans. In this view, repatriating Kennewick Man/the Ancient One to northwestern Native peoples, or to any North American indigenous group for that matter, would represent a serious mistake, since his craniofacial morphology indicated that he was probably not a Native American ancestor.

In articulating their cranium-focused argument, the anthropologists who sued to stop the repatriation eschewed archaeological features about Kennewick Man/the Ancient One that marked him as indigenous to North America. For example, a stone artefact was embedded in one of his pelvic (hip) bones, a spear point that closely associated the remains with the antiquity revealed through radiocarbon dating and with other Palaeoindian groups who would have been in existence during his lifetime. The cultural evidence, however scant, did not point to any far-flung origins for these remains. The anthropologist plaintiffs, though, believed that the presence of the spear point did not reveal Kennewick Man's/the Ancient One's identity. Rather, to them the skull itself was the best predictor of an ancient individual's cultural position. They firmly subscribed to the idea that measurable cranial features are inherited, and when compared to those of other skeletal populations, are reliable indicators of biological relationships between past human groups. The substance of the anthropological arguments was grounded in nearly fifty years of craniometric science and was successful in federal district court, which is one level below the Supreme Court of the United States; therefore many of these decisions are binding. The judge in the case was moved by the scientists' arguments, and ruled that Kennewick Man/the Ancient One, because of his age and cranial morphology, could not be considered 'Native American' under the law. In 2004 the same tribes who would later rebury the Ancient One lost their case, and the remains stayed in curation at the Burke Museum in Seattle. ${ }^{46}$

The court decision validating a non-Indian identity for Kennewick Man/the Ancient One reverberated around the Native American community, and also the community of people who worked in repatriation. Through their use and promotion of craniometry as the method whereby ancient identity may be unlocked, the anthropologist plaintiffs succeeded in consolidating an equivalence between morphology and identity for the ancient past in United States federal law for the first time. Here physical form stands in for cultural identity or ethnicity, a quasi-racial classificatory scheme shrouded in the language of 'population ancestry' and 'biological affinity'. Kennewick Man/the Ancient One became, legally, a 'Palaeoamerican', and the plaintiffs used this term in the academic literature as well as in court filings. ${ }^{47}$ As ontologically distinct from

Dennis P. van Gerven, 'A century of skeletal biology and paleopathology: contrasts, contradictions, and conflicts', American Anthropologist (2003) 105, pp. 53-64. Even though physical anthropologists are divided about the utility of craniometry, critiques of craniometric practice did not factor into the federal district court case.

46 Sarah Graham, 'Scientists win latest ruling in Kennewick Man case', Scientific American, at www. scientificamerican.com/article/scientists-win-latest-rul, accessed 10 November 2016; Joe Watkins, 'Becoming American or becoming Indian? NAGPRA, Kennewick, and cultural affiliation', Journal of Social Archaeology (2009) 4(1), pp. 60-80.

47 Robsen Bonnichsen (ed.), Who Were the First Americans? Proceedings of the 58th Annual Biology Colloquium, Center for the Study of the First Americans, Corvallis: Oregon State University Press, 1999. 
'Indian', Palaeoamerican injected a new vitality into the 'mystery of the first Americans'. ${ }^{48}$ No longer, in America's historical narrative, would Palaeoindians inexorably lead to Indians, an expected Other, who would then be conquered and colonized by people who would eventually name America and create the nations that now occupy indigenous peoples' ancestral lands in the western hemisphere. As the reconfigured story went, Palaeoamericans might have had a bright future, too, if not for the intrusion of the ancestors of American Indians, whose migration via the Bering land bridge as the glaciers receded would bring the mysterious Palaeoamericans to an undeserved early end. The Palaeoamerican, then, was a new material status constructed largely by craniometry, a fresh connection to an American past that even (and perhaps especially) settler colonials might affectively identify with. ${ }^{49}$

Such was the disciplinary and political landscape around Kennewick Man/the Ancient One when, in the early 2010s, geneticists began to take an interest in the few sets of Palaeoindian remains excavated from the western half of the United States. Like craniometrists, geneticists seek to tell stories about the peopling of the western hemisphere, and new research in palaeogenomics has suggested that living Native North American people are descended from a Beringian population whose migrants travelled south as ice receded from the continent. ${ }^{50}$ One particular researcher, Eske Willerslev of the University of Copenhagen, has been involved in the sequencing of the genomes of three of the oldest skeletons found in the United States. ${ }^{51}$ In addition to Kennewick Man/the Ancient One, Willerslev's team has sequenced the genomes of a child's skeleton from Montana (called Anzick Boy) and the Spirit Cave mummy from Nevada. At the time of this writing, all three of these ancient skeletons, previously embroiled in controversy over their status as Native American, have been repatriated and even reburied because of their genetic relatedness to contemporary Native people. ${ }^{52}$ In 2015 , after the genetic results were released, Armand Minthorn of the Umatilla tribe noted,

48 'Mystery of the first Americans', op. cit. (8).

49 See John Harries, 'Of bleeding skulls and the postcolonial uncanny: bones and the presence of Nonosabasut and Demasduit', Journal of Material Culture (2010) 15(4), pp. 403-421.

50 Jennifer A. Raff and Deborah A. Bolnick, 'Paleogenomics: genetic roots of the first Americans', Nature (13 February 2014) 506, pp. 162-163. Jennifer Raff has mounted a noble fight on her blog against another strand of thought that has denied Palaeoindians a relation to modern Native people: the Solutrean hypothesis. Here, certain features of the stone tools made by Palaeoindians are compared to those made in Europe. Those who subscribe to the Solutrean theory believe that there is some kind of biological and cultural connection between Europeans and the First Americans. This is akin to the Palaeoamerican idea, and its proponents often use the anomalous cranial evidence to bolster their case. See Jennifer Raff, 'The oldest American genome and what it tells us about the peopling of the Americas', https://violentmetaphors. com/2014/02/18/the-oldest-north-american-genome-and-what-it-tells-us-about-the-peopling-of-the-americas, accessed 12 September 2017.

51 See e.g. Morten Rasmussen, Martin Sikora, Anders Albrechtsen, Thorfinn Sand Korneliussen, J. Víctor Moreno-Mayar, G. David Poznik, Christoph P.E. Zollikofer, Marcia S. Ponce de León, Morten E. Allentof, Ida Moltke, Hákon Jónsson, Cristina Valdiosera, Ripan S. Malhi, Ludovic Orlando, Carlos D. Bustamante, Thomas W. Stafford Jr, David J. Meltzer, Rasmus Nielsen and Eske Willerslev, 'The ancestry and affiliations of Kennewick Man', Nature (2015) 523, pp. 455-458.

52 There is a much longer story to tell here about Morton Rasmussen, Eske Willerslev and their team's involvement in the sequencing of the DNA of indigenous people around the world, as well as the details of their interactions with Native American people in their investigation of the Palaeoindian genome. For 
Our belief [that Kennewick Man is Native American] was only reconfirmed by Dr. Eske Willerslev ... And the DNA results said, very clearly, that Kennewick Man is Native American. There is DNA that was submitted by the Colville Tribe, and the DNA matched the Kennewick Man. We have always said this. We have always believed it. ${ }^{53}$

These newsworthy confirmations of Palaeoamerican genetic relatedness to modern Native American peoples cast into serious doubt the ability of skeletal biologists to accurately pinpoint the relationships between past and current human populations one of their raisons d'être. Most biological anthropologists are trained to see the skull as a reliable indicator of population affiliation - cranial and facial measurements can reveal a skull's population, or geographical origin, so the rationale goes, because these features are governed by relatively slow microevolutionary processes. ${ }^{54}$ Other anthropologists, however, have recently rejected this practice, and the theory behind it, arguing instead that skull shape and form change too quickly, sometimes from generation to generation. ${ }^{55}$ These anthropologists see broad changes in dietary adaptation reflected in the morphology of skulls, and view them as inventions of human material culture, not as clues to past or current identities. ${ }^{56}$

However, the way in which population relationships are figured in genetic disciplines (including palaeogenomics) claims something that craniometry could never obtain:

example, in the case of the remains from Montana, the daughter of the people who owned the farm on which the remains were found, Sarah Anzick (the remains are named the Anzick Boy), became interested in sequencing the skeleton's genome. Evidently she made contact with a number of Montana tribes and nations, but 'she could not reach a consensus from the tribes on what to do' so she dropped the matter. An archaeologist later convinced her to send a sample from the remains to Willerslev's lab, and later they both faced critique from the tribes because they were not adequately consulted about the genome sequencing beforehand. Ewen Callaway, 'Ancient genome stirs ethics debate', Nature (13 February 2014) 506, p. 142. Nevertheless, the tribes encouraged the reburial of the child, and Anzick granted that request. There are, therefore, a number of sticky ethical issues involved in this and other cases in the genomics of Palaeoindians, and any skeletal remains with possible affiliations to Native American groups. For one, since the skeleton found on the Anzick's farm was found on their private property, the family had possession of the remains and Sarah Anzick owned the remains at the time. Her attempt to consult with Montana tribes is certainly laudable, but without knowing the details of the negotiations, it is difficult to evaluate some of the issues involved. Certainly the Anzicks had previously given scientists access to the remains (the skeleton and associated artefacts were found in 1968), but there is no immediate evidence that they also gave any tribes and nations similar access during the time the remains were in their possession.

53 Minthorn, op. cit. (11).

54 See Rolando González-José, Sylvia L. Dahinten, Maria A. Luis, Miquel Hernández and Hector M. Puccarrelli, 'Craniometric variation and the settlement of the Americas: testing hypotheses by means of $\mathrm{R}$ matrix and matrix correlation analysis', American Journal of Physical Anthropology (2001) 116, pp. 154165; Ann H. Ross, Douglas H. Ubelaker and Anthony B. Falsetti, 'Craniometric variation in the Americas', Human Biology (2002) 74(6), pp. 807-818.

55 Armelagos and Van Gerven, op. cit. (45). See the response from Christopher M. Stojanowski and Jane E. Buikstra, 'Biodistance analysis, a biocultural enterprise: a rejoinder to Armelagos and Van Gerven', American Anthropologist (2004) 106(2), pp. 430-431.

56 For example, the transition to agriculture, wherever it occurred, brought with it a significant shortening of the skulls of people who ate 'processed' food (processed in this case means ground corn, versus the tougher foods typically eaten by hunting and gathering peoples). This craniofacial shortening led to people not having enough room in their mouths for all their teeth. Tooth development and eruption is a highly regulated process, and changes only very slowly, over many millennia. Therefore we can blame the agricultural transition for many people's need to have their wisdom teeth (i.e. third molars) removed. 
genealogy. That genetics is able to make a gesture to kinship through DNA - through mitochondrial DNA haplotypes, for example - allows those living people who share DNA variants with skeletons/ancestors an immediate identification with the people of a distant past. ${ }^{57}$ Genetic genealogy, therefore, can claim affective ties to the living that are unavailable to craniometry. ${ }^{58}$ Kennewick Man/the Ancient One and the other ancient skeletons whose genomes have been sequenced are given another kind of life in the genetic connection to living Native people, one they did not have as anomalous skulls among other skulls. It is the distinction between life (or genetics' closer connection to life) and death that, in part, ironically assures craniometry of its viable future in ancient American archaeology. Geneticists do not prioritize the dead the way craniometrists do. Therefore the burden of proof for ancestral connections to most of the curated skeletal ancestors in the United States remains, at least for now, with indigenous people. These collections have been maintained and controlled by anthropologists for decades, and it is also biological anthropologists who most frequently have worked in (and against) repatriation. Craniometrical schemes have often only confirmed a lack of connection because of differences in morphology, even if skeletal individuals were excavated from Native people's ancestral lands. Fundamentally, then, disparate genetic results from a few rare and well-publicized cases do not immediately challenge craniometry's claim to the distant past.

Even though genetic analyses have largely settled the Palaeoindian-versusPalaeoamerican debate and hastened the demise of the Palaeoamerican in American archaeology, the similarities between craniometry and genetics as developed Western sciences, I would argue, outweigh their differences. The kinds of population comparison that both fields use were structured in nearly the same way. For craniometry, a database constructed in the 1960s of hundreds of measurements from only twenty-eight different geographic populations is understood within the field to encompass most of the world's cranial variation. ${ }^{59}$ Similarly, geneticist Luca Cavalli-Sforza based his 'worldwide' genetic analysis on only fifteen populations, named variously by location, culture or historical group. ${ }^{60}$ Genetics may supplant craniometry by depriving it of its authority to classify ancient skeletons, but this is not an emancipatory victory. Neither craniometry

57 For example, we can all pay a less than nominal fee to discover our 'genetic relatives' through the numerous genomic for-profit services that promise us greater understanding of our genetic heritage. Only the most serious students of human osteology walk around evaluating their cranial form against those of the people they meet on the street.

58 The affective ties produced by genetics, specifically the perception of the extraordinary authority of genetics over matters of kinship, is also worthy of interrogation. For more see Jenny Reardon and Kim TallBear, "Your DNA is our history": genomics, anthropology, and the construction of whiteness as property', Current Anthropology (2012) 53(S5), pp. 233-245.

59 W.W. Howells, Cranial Variation in Man: A Study by Multivariate Analysis of Patterns of Difference among Recent Human Populations, Cambridge, MA: Harvard University Press, 1973; Benjamin M. Auerbach, The William W. Howells Craniometric Data Set, at https://web.utk.edu/ auerbach/HOWL. htm, accessed 9 September 2017.

60 See Marianne Sommer, 'Population-genetic trees, maps, and narratives of the great human diasporas', History of the Human Sciences (2015) 28(5), pp. 108-145, 118. 
nor genetics is overly concerned with the deconstruction of received conceptions of human difference. ${ }^{61}$ Further, craniometric and genetic conceptions of the ancient past align if compared with Native perspectives. Despite their interpretive disagreements, few contemporary geneticists or craniometrists would subscribe to the far more capacious indigenous ethic of genealogy and relatedness, one that has never relied on - and has even strongly eschewed - scientific standards of evidence. Native peoples' spiritual and relational ethics often include their ancestors and the ancestors of other Native peoples, and count as kin both the land and the animals that live on it. ${ }^{62}$ Science, with its strict classifications and Western separation of people from nature, has had a central role to play in the adjudication of repatriation claims. The criteria mandated by NAGPRA to determine the links between living and past Native groups - dubbed 'cultural affiliation' in the law - has often been heavily weighted on the side of the biological. That is, in the absence of sacred or other objects that can be definitively linked to specific living Native American groups, skeletons, and sometimes the DNA obtained from them, become the main lines of evidence that make or break a repatriation claim. This is why the construction and perpetuation of the concept of Palaeoamerican, one that separated modern Native people from the ancient American past, could have irrevocably changed the landscape of repatriation in the United States.

\section{Difficult ends and arduous beginnings}

Despite all I have written here, it is possible that the Palaeoamericans will not end. Perhaps new archaeological finds will illuminate a non-Indian or non-indigenous origin for the ancient Americas that archaeologists and physical anthropologists can investigate further as a valid Palaeoamerican past. Or perhaps some of the existing Palaeoindians will yield substantial genetic differences from Native American people. So far, however, this potential future has not materialized. Recent genetic analysis of a young girl's skeleton found in Yucatán in Mexico, described as having the 'Palaeoamerican phenotype', also confirmed the other recent results discussed above: she is a genealogical ancestor of modern indigenous people. ${ }^{63}$ The skeleton, named 'Naia', was found in an underwater cave and was analysed, in part, by the very same archaeologist, James Chatters, who originally collected the Kennewick Man/Ancient One remains. This research experience has shifted Chatters's thinking: he was an early and active proponent of Palaeoamericans, and was convinced of Kennewick Man's/

61 See Troy Duster, 'A post-genomic surprise: the molecular reinscription of race in science, law and medicine', British Journal of Sociology (2015) 66(1), pp. 1-27.

62 See Winona LaDuke, All Our Relations: Native Struggles for Land and Life, Cambridge, MA: South End Press, 1999.

63 James C. Chatters, Douglas J. Kennett, Yemane Asmerom, Brian M. Kemp, Victor Polyak, Alberto Nava Blank, Patricia A. Beddows, Eduard Reinhardt, Joaquin Arroyo-Cabrales, Deborah A. Bolnick, Ripan S. Malhi, Brendan J. Culleton, Pilar Luna Erreguerena, Dominique Rissolo, Shanti Morell-Hart and Thomas W. Stafford Jr, 'Late Pleistocene skeleton and mtDNA link Paleoamericans and modern Native Americans', Science (2014) 344(6185), pp. 750-754. 
the Ancient One's separation from modern Native people. ${ }^{64}$ 'Naia', though, will probably not be repatriated to anyone, or reburied, as the politico-legal climate in Mexico is very different from that in the United States. The indigenous peoples of Mexico are not considered sovereign entities, as are the more than 550 tribes and nations in the United States. Indian sovereignty in both the United States and Canada - where tribes and nations have a government-to-government relationship with their federal governments - has played a key role in repatriation efforts, and grounds these movements in more than just cultural or moral authority. As I have argued elsewhere, the penchant in the scientific community has been to see repatriation as an unqualified 'win' for Native people, based mostly on those people's identities as indigenous; rather, the reality of repatriation has shown both Native people and scientists that the process is better described as the enactment of a set of mutual responsibilities. ${ }^{65}$ Perhaps the most fundamental end involved in repatriation, therefore, has been that of the traditional roles that scientists and Native peoples occupied vis-à-vis relationships with each other, and the stewardship of scientists over Native American material history.

Furthermore, NAGPRA has also, in its nearly thirty years of existence, succeeded in ultimately satisfying no one: Native people claim it proceeds too slowly, resistant anthropologists claim it moves too quickly, and funding for its actualization has always been meagre according to everyone involved. Nevertheless, the repatriation movement and NAGPRA have collectively changed the conditions under which the indigenous American past is studied and preserved. Now, at least in the United States, scientists have a responsibility to recognize that anthropology, archaeology and museum studies have always been deeply imbricated in the nation's colonial history and politics. To claim that repatriation is ideological and science is somehow not - something that opponents of repatriation have done regularly - not only has failed as an argumentative strategy, but also is patently incorrect historically. As mentioned briefly above, the large public and private collections of both Native skeletal and material remains were made possible only by the political weakening of American Indian peoples. The collection booms of the late nineteenth century and the first third of the twentieth mark the lowest moments of Native American political influence in the United States. When, after 1934, tribes and nations were able to reconstitute their governments through the federal Indian Reorganization Act, they resumed their resistance to both archaeological and institutional collecting. Along these lines, I have also asserted elsewhere that scientists should begin to see themselves as members of a descendant community: our disciplinary forebears participated in the amassing of Native materials, and we are now responsible for how some of those collections are bound to end. ${ }^{66}$

64 Sandi Doughton, 'Ancient girl's skeleton changes scientist's mind on human migration', Seattle Times, 16 May 2014, at www.seattletimes.com/seattle-news/ancient-girlrsquos-skeleton-changes-scientistrsquos-mindon-human-migration, accessed 20 February 2018.

65 Ann M. Kakaliouras, 'NAGPRA and repatriation in the twenty-first century: shifting the discourse from benefits to responsibilities', Bioarchaeology International (2017) 1(3-4), pp. 183-190. In that piece I also enumerate in more detail the responsibilities that Native people take on when entering into repatriation claims.

66 Kakaliouras, op. cit. (65), pp. 187-188. 
Archaeologists, anthropologists and museum workers also share a responsibility to not treat repatriation as charity, benevolence or appeasement. Repatriation will work differently in different places, but repatriation claims are distinctly legal and political acts. It is certainly possible for scholars and researchers to disagree with the idea or processes of repatriation, but to cast our roles as caring benefactors simply upholds the same patriarchal and patronizing colonial power relationships that repatriation is beginning, slowly and fitfully, to help dismantle. Power sharing and collaborative stewardship of the past have not been the end of anthropology in North America. Contemporary encounters with ancient objects and ancestral remains are attached to a series of valid historical and sociopolitical commitments from multiple stakeholders, from museum directors, to anthropological educators, to indigenous ritual specialists, to indigenous political leaders, and to everyday people, indigenous or not.

Lastly, and perhaps most controversially, academics and researchers have, like so many others, inherited a perception that the institutions located in our urban centres are the most viable stewards of the pre-industrial past. Advances in preservation technology have reinforced this view. But professionals and their audiences can only encounter this past as appreciative tourists and not as politically and legally empowered descendants of living, or revitalized, traditions and cultural practices. With repatriation, some of those descendants are asserting their wish to see the products of their pasts distributed more freely in the present. Or they believe that such materials, to best act in the world, should not be preserved at all, a valid choice for culturally independent and sovereign entities. There are examples of Native North American peoples who have received human remains and sacred objects, only to bury them in acidic soils, or allow them to degrade in the natural environment. ${ }^{67}$ The preciousness of archaeological materials to Westerners makes parting with them difficult, and makes knowing that their material existence has ended especially painful. While we may invoke some sort of right to preserve special and rare anthropological materials - such as the Palaeoamericans - as a core European or Euroamerican cultural value, this right has not, at least recently, superseded the rights of lineal and cultural descendants to exercise their ability to have those materials back and to do with them what they wish.

It appears, unfortunately to some, and fortunately to others, that the Palaeoamericans will eventually come to an end. News of their repatriations or reburials has come out much more slowly and with much less media coverage than their finds and the craniometric results that led to the controversies over their Indianness. The concept of Palaeoamerican itself can end with no fanfare at all, but through the gradual atrophy of its scientific credibility. That genetic lines of evidence are considered more trustworthy markers of cultural identity than cranial morphology, by both scientists and Native peoples, is itself a new development that may hasten the ends of other collections, or may be supplanted by yet other scientific advances. While the already reburied

67 William L. Merrill, Edmund J. Ladd and T.J. Ferguson, 'The return of the Ahayu:da: lessons for repatriation from Zuni Pueblo and the Smithsonian Institution', Current Anthropology (1993) 34(5), pp. $523-567$. 
Palaeoamericans are now lost to science, their legacy will likely continue with the data and interpretations that have been produced from them. As I have attempted to make clear in this article, though, material ends and ephemeral or cultural ends do not always travel the same trajectories. These ancient people will most likely live on most intensely for the Native peoples who call them ancestors. 